\title{
Test Plan for Composting Studies Involving Weight and Volume Reduction of Leaf and Stalk Biomass: DOE/OTD TTP\# SR17SS53 \& TTP\# SR18SS41
}

by

E. W. Wilde

Westinghouse Savannah River Company

Savannah River Site

Aiken, South Carolina 29808

J. Kastner

C. Murphy

J. Santo Domingo

This paper was prepared in connection with work done under the above contract number with the $U$. $S$. Department of Energy. By acceptance of this paper, the publisher and/or recipient acknowledges the U.S. Government's right to retain a nonexclusive, royalty-free license in and to any copyright covering this paper, along with the right to reproduce and to authorize others to reproduce all or part of the copyrighted paper. 


\section{DISCLAIMER}

This report was prepared as an account of work sponsored by an agency of the United States Government. Neither the United States Government nor any agency thereof, nor any of their employees, makes any warranty, express or implied, or assumes any legal liability or responsibility for the accuracy, completeness, or usefulness of any information, apparatus, product, or process disclosed, or represents that its use would not infringe privately owned rights. Reference herein to any specific commercial product, process, or service by trade name, trademark, manufacturer, or otherwise does not necessarily constitute or imply its endorsement, recommendation, or favoring by the United States Government or any agency thereof. The views and opinions of authors expressed herein do not necessarily state or reflect those of the United States Government or any agency thereof.

This report has been reproduced directly from the best available copy.

Available to DOE and DOE contractors from the Office of Scientific and Technical Information, P. O. Box 62, Oak Ridge, TN 37831; prices available from (423) 576-8401.

Available to the public from the National Technical Information Service, U. S. Department of Commerce, 5285 Port Royal Road, Springfield, VA 22161. 


\section{DISCLAIMER}

Portions of this document may be illegible electronic image products. Images are produced from the best available original document. 
Test Plan for Composting Studies Involving Weight and Volume Reduction of Leaf and Stalk Biomass: DOE/OTD TTP\# SR17SS53 \& TTP\# SR18SS41

by

Ed Wilde

Jim Kastner

Chas Murphy

Jorge Santo Domingo

Westinghouse Savannah River Company

Savannah River Site

Aiken, South Carolina 29808

Approved by: T.C. Hazen

Environmental Biotechnology Section

Savannah River Technology Center 
Test Plan Summary

Objectives

Background

Experimental Approach

Conduct Literature Review and Choose Feedstocks

Obtain plant material (feedstocks) for experimental work at SRS 9

Characterize Feedstock 9

Experimental Design 10

Outline of Procedures 11

Bench Scale Composting Experiments 11

Degradation Kinetics - Correlation with Microbiological Data Micro-composter Studies: Mini-composter Studies 16

Pilot-Scale Composters

Safety'

Quality Assurance 22

Security

Subcontracts 


\section{Test Plan Summary}

Savannah River Technology Department (SRTC) Personnel and a panel of experts from universities and industry have suggested that composting is the most attractive alternative for reducing the volume and weight of slightly radioactive biomass. This test plan involves bench scale studies to assess the rates and efficiencies of various composting schemes for volume and weight reduction of leaf and stalk biomass (LSB). The data should be useful for designing a composting process for dealing with radioactive biomass harvested at the Savannah River Site (SRS). This could drastically reduce costs for transporting and disposing of contaminated biomass at the site. The composting studies at SRTC include collaboration with personnel from the University of Georgia, who will conduct chemical analyses of the plant material after harvest, pre-treatment, and composting for specific time periods. Parameters to be measured will include: lignin, hemicellulose, cellulose, carbon and nitrogen.

Milestones for the project are as follows:

Obtain plant material and begin composting experiments-_-_._-6/30/97

Complete bench-scale composting experiments-_____- $6 / 30 / 98$

Complete technical report for project-_- 7/31/97

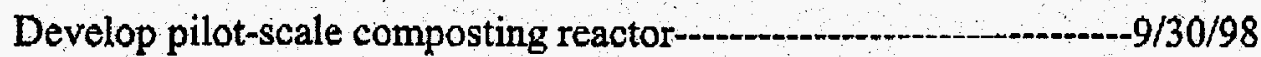

\section{Objectives}

The overall objective of this project is to identify or develop: (1) an inexpensive source of inoculum (consisting of nutrients and/or microorganisms) capable of significantly enhancing biomass degradation, (2) an optimum range of operating parameters for the composting process, and (3) a process design for the solid state degradation of lignocellulosic biomass contaminated with radionuclides that is superior to existing alternatives for dealing with such waste.

Specific goals for the first year of the project are to:

- determine a source of inoculum for the composting operation which is economical (e.g., local source),

- determine the rate of solid waste degradation (i.e., the time required for significant solid waste degradation),

- determine if pretreatment(s) will significantly increase the rate of solid waste degradation, 
- determine the influence of particle size, moisture content, and temperature on the rate and extent of solid waste reduction, and

- acquire data needed to design a large scale composting process/reactor

The principal goal in subsequent years will be to use the above data to design a large scale composting operation at SRS for the volumetric reduction of radioactively contaminated biomass. Composting is safer then other forms of volume reduction such as incineration because the natural biodegradation of biomass takes place at temperatures far below those needed for volatilization of radioactive gases.

\section{Background}

The cleanup of radiologically contaminated waste sites at the SRS requires removal of vegetation that has taken up radioactive compounds from the soil. This vegetation typically has low levels of radioactivity per unit biomass, but is massive in size. It is estimated that $40,000 \mathrm{cu}$. yds of radiologically contaminated vegetation have grown naturally on contaminated soils at the site (Wilde et al., 1996). Phytoremediation (planting and harvesting crops specifically for the remediation of contaminated soils) would result in considerably more of this material for disposal. The most likely ultimate disposal method for radioactively contaminated biomass will be shipment off-site for incineration or burial in a licensed landfill. The cost of either of these options is computed by the weight and/or volume of the material to be shipped. Thus, an inexpensive process for reducing the volume and weight of the contaminated biomass prior to off-site shipment could result in substantial savings for DOE.

Composting is a process in which a source of nutrients and microorganisms are added to a solid waste and microbial growth stimulated by aeration. The resultant aerobic growth subsequently leads to conversion of solid waste into mineralized nutrients, $\mathrm{CO}_{2}$ and $\mathrm{H}_{2} \mathrm{O}$. Thus, a significant fraction of the solid waste, typically composed of polymers such as starch, protein, cellulose, hemicellulose, and lignin are broken down and released as $\mathrm{CO}_{2}$. This results in a large decrease in solid waste mass. More importantly, the process occurs at relatively low temperatures $\left(40-50^{\circ} \mathrm{C}\right)$ and is a self-heating process requiring a relatively inexpensive catalyst. Because of low temperature and pressure requirements, inexpensive materials can be used in the construction of the bioreactors. In addition to the current project, composting could have considerable applicability at SRS in terms of handling non-radioactive waste, such as the garbage generated on site and the wastes that will be coming to the site for disposal at the new Three Rivers Landfill.

Composting processes are primarily designed to stabilize a waste (i.e., oxidize the easily degradable fraction such as proteins and soluble carbohydrates) and provide an organic fertilizer. In most composting processes the substrate or feedstock has an adequate microbial population and nutrient levels; the only rate limiting steps are physical 
processes such as aeration. Thus, in most operations an inoculum and nutrient source are not needed. However, in our case the feedstock may not contain a high enough microbial population or nutrient level to stimulate solid waste consumption (e.g., lignocellulosic materials contain high levels of carbon but very low levels of nitrogen and phosphorous). To stimulate solid waste degradation, the right ratio of feedstocks/nutrients/inoculum are required. The objective of our process is to minimize the amount of nutrients and inoculum added to the feedstock, yet provide rapid biological decomposition of the feedstock.

There are two basic types of composting operations, open and closed or in-vessel systems. The open systems consist of the windrow operation and static aerated piles (Figures 1 and 2). In the windrow process piles of solid waste are periodically turned to promote oxygen transfer, whereas in static aerated piles air is forced through solid waste piles via vacuum extraction or injection. In vessel designs are closed reactors in which the method of aeration and mixing of the solid matrix varies. The suggested advantage of the in-vessel designs are that they shorten the composting process, potentially by maintaining a more uniform and controlled environment (Viel et. al., 1987). Open systems also have the problem of particulate loss if the solids become too dry.

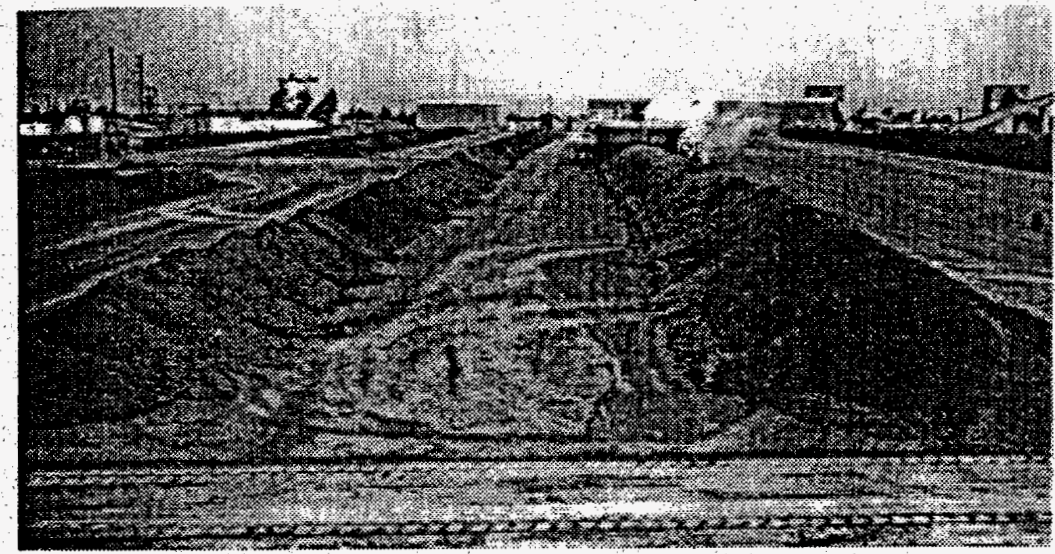

Figure 1: Example of windrow composting operation (taken from Metcalf \& Eddy, 1991). 


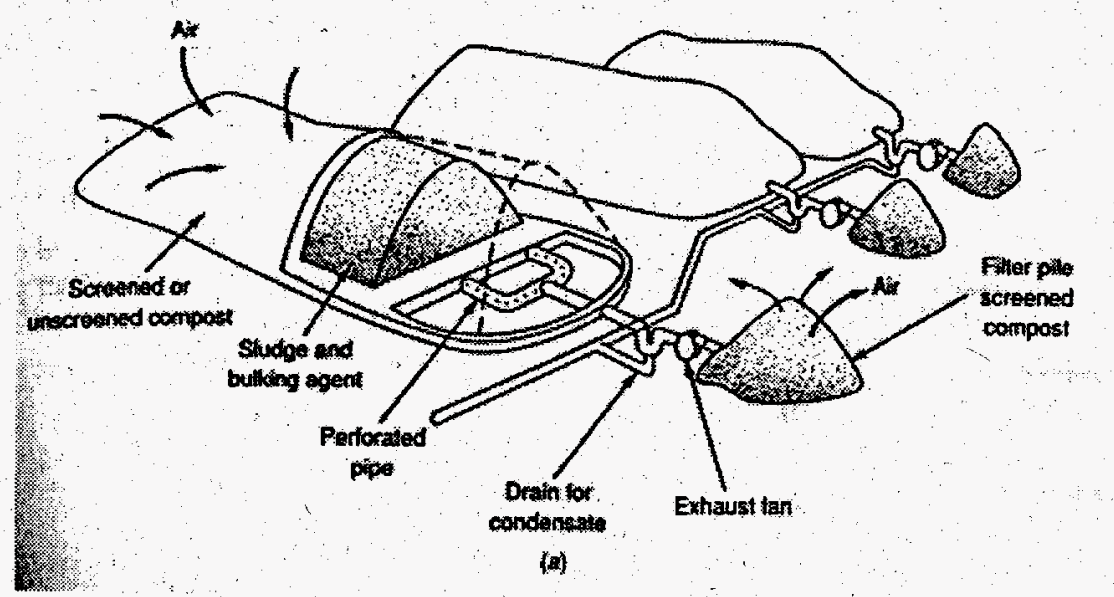

Figure 2: Example of static aerated pile composting operation (taken from Metcalf \& Eddy, 1991)

Thus, an in-vessel design will be used in this project to prevent the loss of particulate and associated radiologically contamination. Two types of in-vessel designs have been proposed, continuous and batch (Figures 3 and 4). In both processes the approach to reactor design is too maximize air and solids contact too promote oxygen and heat transfer. Continuous processes are typically more complex and have higher capital and operating costs. Continuous reactors are also typically larger than batch reactors, since 20-30 day retention times are required to treat the solid waste.

It is likely that radiologically contaminated vegetation will be quickly harvested and stored in vessels for transport off-site. Thus, the feedstock source will be discontinuous (i.e., periodic) and will vary in composition (seasonal changes may dictate that different plants be used), which dictates a flexible and simple reactor design. 

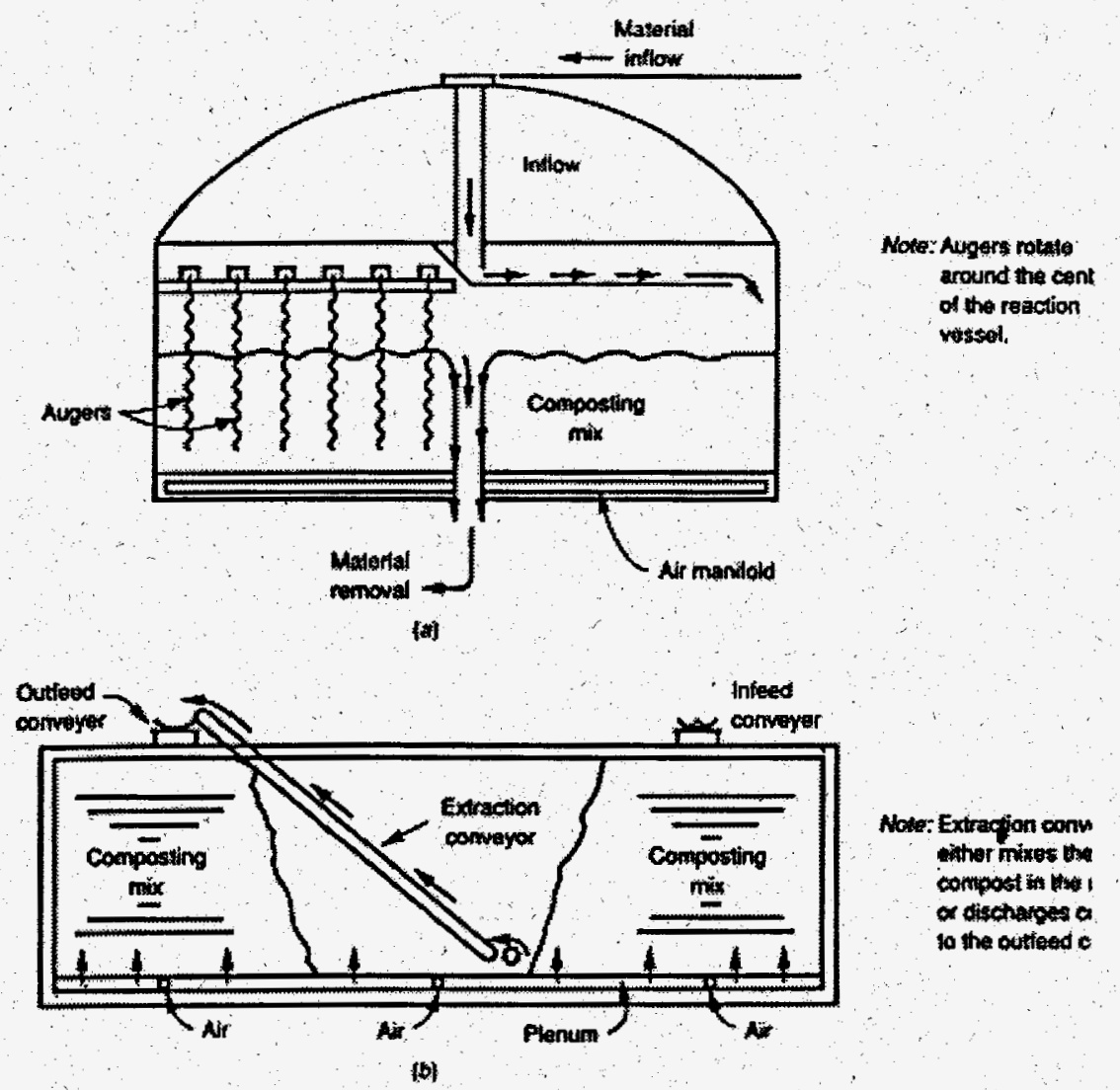

Figure 3: Continuous in-vessel composting systems using circular mixing (A) or conveyor mixing (B) (taken from Metcalf \& Eddy, 1991). 


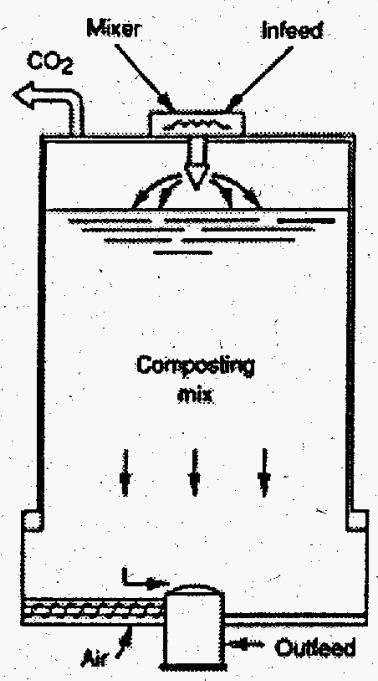

(a)

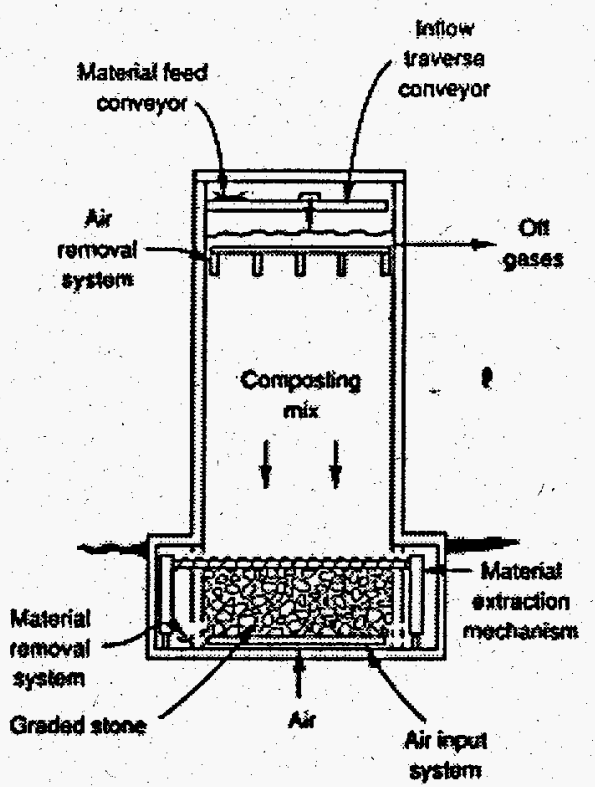

(b)

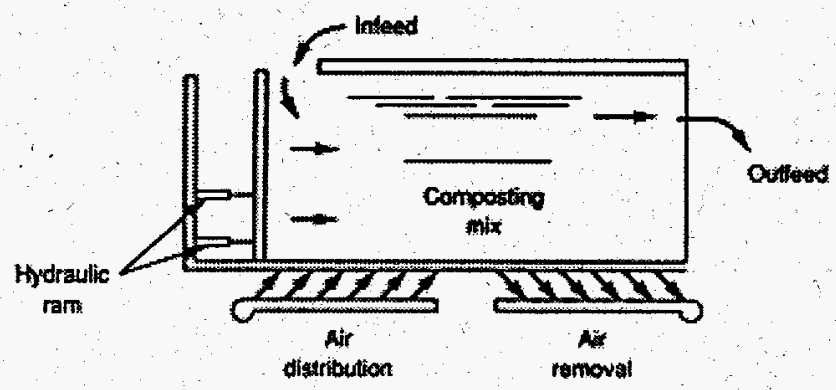

Figure 4: Composting systems using continuous plug (air) flow, packed bed reactors (taken from Metcalf \& Eddy, 1991).

It is felt that a batch process using controlled aeration would provide the greatest flexibility at the lowest cost. Our approach will involve modifying the storage vessels to promote oxygen mass transfer (e.g., a perforated false floor) and periodic manual mixing or material addition. Air flow may be designed to flow upwards through the solid matrix or sideways from one end of the reactor to the other. Each reactor or a series of reactors will be manifolded to a compressor and flow meter. Thus, separate reactors can be added or taken off-line depending on the stage of solid waste decomposition. Additional blowers and manifolds could be set up depending on the volume of waste to be treated. Temperature and oxygen concentration will probably be controlled by reactor temperature feedback on the airflow rate (e.g., if the measured reactor temperature rises above the set-point, the airflow is increased). Previous research has shown that the mass of air required to transfer heat from the compost reactor and maintain the temperature below the self-destruction stage provides adequate oxygen levels (Finstein and Hogan, 1985). 


\section{Experimental Approach}

The work has been subdivided into work elements. Many of the following work elements will be conducted concurrently, while others are dependent on completion of a preceding element.

\section{Conduct Literature Review and Choose Feedstocks}

Consult literature and appropriate experts for design of the experimental procedures, significant compost conditions, and the most appropriate plant species to evaluate. An initial review of the literature on this subject (Wilde et. al 1996) has indicated the following optimal parameters for a composting operation:

- Particle Size: $<0.25$ inches

- Moisture Content: $60 \%(\mathrm{w} / \mathrm{w})$

- Temperature: $50^{\circ} \mathrm{C}$

- pH: 6-7 (initial)

- C/N ratio: $30: 1$

- Excess Oxygen: $>15 \%$ (in air)

Additional literature will be consulted and cited in the final report for the subtask.

\section{Obtain plant material (feedstocks) for experimental work at SRS}

Plants that have been suggested by MSE as potential candidates for their FY 1997/98 studies at SRS include: Redroot Pigweed (Amaranthus retroflexus), other spp of Amaranthus, Indian Mustard (Brassica juncea), Bahia Grass (Paspalum notatum), Beets (Beta vilgaris), Cabbage (Brassica oleracea), and Corn (Zea Mays). Based on consultation with MSE and local agricultural experts it was determined that corn and cabbage would be the most appropriate species to select for initial experiments. Other species selected by MSE will be grown in a greenhouse at SRS (from seed provided by MSE) and tested as time allows. Harvested plant material will be stored in a walk-in cooler prior to being used in composting experiments.

\section{Characterize Feedstock}

Aliquots of the collected plant material will be sent to a university partner (University of Georgia) to determine initial composition in terms of the $\%$ of water soluble carbohydrates, \% cellulose, \% hemicellulose, \% lignin, and the carbon to nitrogen $(\mathrm{C} / \mathrm{N})$ ratio. 


\section{Experimental Design}

Ultimately, the objective of this project is to develop a reactor design to promote solid waste degradation. A forced aeration system in a packed bed reactor (enclosed reactor) is envisioned. The first step will be to measure the intrinsic rate of degradation (rate of degradation assuming the biofilm is under ideal conditions; e.g., uniform temperature and oxygen mass transfer not rate limiting, and bioavailable nutrients). Once the intrinsic rate of degradation is measured, the holding time required for optimum waste reduction can be calculated. Next, reactors will be designed to maintain the intrinsic rate of degradation when the process is scaled to a larger size. Three types of test bioreactors are envisioned for the composting research: (1) micro-composters to screen process variables, (2) minicomposters to test scale-up and control schemes, and (3) pilot-scale composters to test reactor designs. The micro-composter experiments (screening experiments) will be performed in duplicate or triplicate and significant results will be replicated.

Experiments at the larger scale will probably not be performed in duplicate, but significant results will be replicated assuming time and money are available. Parameters that will be measured during the studies include the following :

- weight

- volume

- temperature

- Oxygen utilization

- $\mathrm{CO}_{2}$ evolution

- moisture content

- microbial composition

A matrix showing the variables that will be evaluated in the experiments and the type of test units used for each variable is shown in Table 1 below.

Table 1. Test methods for key variables

\begin{tabular}{|l|c|l|l|l|c}
\hline Variable Tested & $\begin{array}{l}\text { Micro- } \\
\text { composter }\end{array}$ & $\begin{array}{l}\text { Mini- } \\
\text { composter }\end{array}$ & $\begin{array}{l}\text { Pilot-scale } \\
\text { composter }\end{array}$ & $\begin{array}{l}\text { Microbial } \\
\text { Analysis }\end{array}$ & $\begin{array}{l}\text { Chemical } \\
\text { analyses }\end{array}$ \\
\hline Pre-treatment & $\mathrm{X}$ & & & $\mathrm{X}$ & $\mathrm{X}$ \\
\hline Nutrient addition & $\mathrm{X}$ & & & $\mathrm{X}$ & $\mathrm{X}$ \\
\hline Temperature & $\mathrm{X}$ & & & $\mathrm{X}$ & $\mathrm{X}$ \\
\hline Moisture content & $\mathrm{X}$ & & & $\mathrm{X}$ & $\mathrm{X}$ \\
\hline Particle size & $\mathrm{X}$ & & & $\mathrm{X}$ & $\mathrm{X}$ \\
\hline Scale-up & & $\mathrm{X}$ & $\mathrm{X}$ & $\mathrm{X}$ & $\mathrm{X}$ \\
\hline
\end{tabular}




\section{Outline of Procedures}

- Step \#1: Prescreening the effect of the feedstock to inoculum ratio. The ratio of feedstock to inoculum will be defined by the $\mathrm{C} / \mathrm{N}$ of $30: 1$. This ratio will be obtained by mixing the inoculum (source of nutrients) and feedstocks. Experiments will be performed at different feedstock to inoculum ratios to test the effect of nutrient and initial cell density levels.

- Step \#2: Once the optimum ratio of feedstock to nutrient amendment (inoculum as well) has been established, the solid waste degradation rates will be compared between the different inoculum. For these experiments, all initial conditions will be defined at reported optimum conditions (particle size $<0.25$ inches, moisture content $60 \%(\mathrm{w} / \mathrm{w})$, temperature $40-50^{\circ} \mathrm{C}$, initial $\left.\mathrm{pH} 6-7\right)$ and oxygen $>15 \%$ in air). The inoculum that gives the highest rate of solid waste degradation will be used to screen the process variables in the scale-up experiments.

- Step \#3: Screening Process Variables. Small bench scale reactors (microrespirometer) will be used to test the effect of pretreatments, temperature, moisture content, and particle size. Degradation rates will be measured in the small reactors and used to estimate the holding time required for maximum solid waste conversion. The reactor volume will be approximately $50-100 \mathrm{ml}\left(\mathrm{cm}^{3}\right)$. These small volumes should allow for uniform temperature and oxygen concentrations within the solid waste. This will allow us to determine the maximum rate of degradation (i.e., intrinsic rate with all rate limiting steps eliminated).

- Step \#4: Intermediate scale reactors (mini-composter) - effect of scale-up. Packed bed reactors will be designed and used to test the effect of scale-up on the rate of solid waste degradation. The packed bed reactors will be approximately 3 " (ID) $\mathrm{X}$ 12 " (length), which gives an approximate volume of $1400 \mathrm{ml}\left(\mathrm{cm}^{3}\right)$. Air will be passed through the reactors to simulate the conditions in the large scale system. The effect of different control procedures for temperature and moisture will be tested in these reactors.

Step \#5: Pilot Scale Reactors. Large-scale reactors will be designed to implement the optimum conditions determined at the bench scale. The reactor may be developed from storage vessels typically used for off site shipment. Temperature and moisture control schemes developed at the bench scale will be implemented to determine the rate of solid waste degradation in the field.

\section{Bench Scale Composting Experiments}

Initially, all composting variables will be defined based on the literature (e.g., moisture content, particle size, initial temperature, $\mathrm{C} / \mathrm{N}$ ratio, etc.) and the inoculum varied. Experimental protocols will include mixing the ground feedstock with the inoculum and adding additional water as needed to achieve the defined moisture content. Subsamples will be obtained for analysis of composition and microbiology. 


\section{Nutrient/Inoculum Amendments}

The following types of nutrient amendments have been suggested:

(1) Activated sludge from SRS Wastewater Plant: source of nutrients and microorganisms

(2) Poultry manure from a commercial vendor: source of microorganisms and limited nutrients

(3) Cricket feces ("Kricket Krap") from Brico Farms in Augusta: source of microorganisms and nutrients

(4) Urea from a commercial vendor: nutrient source only

(5) Finished Compost (mature compost in which cellulose, hemicellulose and lignin degradation has been initiated): source of microorganisms and limited nutrients

(6) Control--no additional nutrients added

Experiments for inoculum screening will be done using the micro-composters, which are bench scale reactors with constant headspace regeneration. The objectives of these experiments will be to determine an effective source of nutrients and microorganisms which can be used to stimulate solid waste reduction. Since, initial cell density and nutrient concentration will effect the rate of solid waste degradation, the feedstock to inoculum ratio will be varied. The ratios will be based on estimated $\mathrm{C} / \mathrm{N}$ ratios of the feedstock and inoculum. Solid waste degradation will be initiated by heating the reactors up to a defined temperature $\left(50^{\circ} \mathrm{C}\right)$ using a water bath. The rate of degradation will be followed by measuring $\mathrm{CO}_{2}$ evolution and $\mathrm{O}_{2}$ consumption. Previous composting of bark has shown these parameters to be useful in estimating the rate of lignocellulosic decomposition (Campbell et al., 1990). Respiration rates, combined with total weight loss measurements (time zero and endpoint analysis) will be used to determine the most effective inoculum. Data should be acquired within 30 days which will show any distinct difference between the inoculums; composting of bark (a lignocellulosic) in small reactors has been accomplished within 30 days (Campbell et al., 1990). Each condition will be run in duplicate and the experiments replicated. Inoculum testing design is shown in Table 2. 
Table 2: Experimental Design for Inoculum Testing.

\begin{tabular}{|l|c|c|}
\hline Inoculum & Feedstock 1 (Corn) & Feedstock 2 (Cabbage) \\
\hline Water Only (Control) & + & + \\
\hline Sewage sludge & + & + \\
\hline Urea & + & + \\
\hline Manure & + & + \\
\hline Finished Compost & + & + \\
\hline
\end{tabular}

\begin{tabular}{|l|c|c|c|c|c|}
\hline $\begin{array}{l}\text { Feedstock/Inoculum Mass } \\
\text { Ratio (dry basis) }\end{array}$ & Control & $\begin{array}{l}\text { Urea or } \\
\text { fertilizer }\end{array}$ & Sludge & Manure & Compost \\
\hline No Amendment & + & & & & \\
\hline $50 / 1$ & & + & + & + & + \\
\hline $25 / 1$ & & + & + & + & + \\
\hline $12.5 / 1$ & & & + & + & + \\
\hline $10 / 1$ & & & + & + & + \\
\hline
\end{tabular}

\section{Effect of Temperature}

Previous work has shown that solid waste degradation rates are faster at $40^{\circ} \mathrm{C}$ (mesophilic), compared to $50^{\circ} \mathrm{C}$ (thermophilic) and $60^{\circ} \mathrm{C}$ (Campbell, 1990). Moreover, microbial activity and degradation rates have been reported to be higher at mesophilic temperatures, potentially due to higher microbial diversity (Finstein and Hogan, 1985). However, the optimal temperature for composting plant material for maximum volume reduction in minimum time may vary with the feed stock. The experimental design for evaluating the effects of temperature is shown in Table 3 below.

Table 3: Experimental Design to Test the Effect of Temperature on the Rate of Solid Waste Degradation.

\begin{tabular}{|l|l|l|}
\hline & Defined Parameters & $\begin{array}{l}\text { Inoculum, Particle Size, } \\
\text { Moisture Content........ }\end{array}$ \\
\hline Temperature & Feedstock 1 (Corn) & Feedstock 2 (Cabbage) \\
\hline Ambient $\left(25^{\circ} \mathrm{C}\right)$-Control & + & + \\
\hline $40^{\circ} \mathrm{C}$ & + & + \\
\hline $50^{\circ} \mathrm{C}$ & + & + \\
\hline $60^{\circ} \mathrm{C}$ & + & + \\
\hline
\end{tabular}




\section{Pretreatment Experiments}

Pretreatment effects will be tested using the micro-composters. The purpose of these experiments will be to test the effect of pretreatment on the rate of degradation.

Lignocellulosics, such as agricultural residues, are mainly composed of three polymers cellulose, hemicellulose, and lignin. Pretreatment by physical or chemical methods, such as steam explosion or acid hydrolysis, can hydrolyze hemicellulose (the glue that holds cellulose and lignin together) and partially hydrolyze cellulose. Oxygen and $\mathrm{CO}_{2}$, along with the dry weight and volume of the final product will be used to evaluate pretreatment (chemical and/or physical, including particle size) effects on the harvested biomass. The basic experimental design is shown in Table 4. Because of the extensive cost of chemicals (e.g., acid catalysts) and capital equipment required for the process, hydrolysis using steam will be the only treatment considered (steam, high pressure or microwave heating of the samples). Previous research has indicated that heat treatment of lignocellulosics can induce autohydrolysis of hemicellulose, thus potentially releasing soluble carbohydrates for microbial growth.

Table 4: Experimental Design to Test the Effect of Pretreatments on the Rate of Solid Waste Degradation.

\begin{tabular}{|l|c|c|}
\hline & $\begin{array}{l}\text { Inoculum - (e.g., Sewage } \\
\text { Sludge }\end{array}$ & \\
\hline Pretreatment & Feedstock 1 (Corn) & Feedstock 2 (Cabbage) \\
\hline Water Only (Control) & + & + \\
\hline Autoclaving & + & + \\
\hline Microwaving & + & + \\
\hline
\end{tabular}

\section{Influence of Particle Size}

Experiments will be conducted with the micro-composters to determine effect of particle size on composting efficiency and identify the optimum particle size. Particle size has been shown to effect the rate of composting. A quote taken from the Cornel Web Page on Composting indicates the importance of particle size. "Decomposition occurs primarily on or near the surfaces of particles, where oxygen diffusion into the aqueous films covering the particle is adequate for aerobic metabolism, and the substrate itself is readily accessible to microorganisms and their extracellular enzymes". Small particles have more surface area per unit mass or volume than large particles, so if aeration is adequate small particles will degrade more quickly. Experiments have shown that the process of grinding compost materials can increase the decomposition rate by a factor of two (Gray and Sherman, 1970). Gray et al. (1971) recommend a particle size of 1.3 to 7.6 $\mathrm{cm}(0.5$ to 2 inches), with the lower end of this scale suitable for forced aeration or continuously mixed systems, and the upper end for windrow and other passively aerated 
systems. We envision a forced aeration system within an enclosed reactor for the composting of radiologically contaminated biomass due to health and safety concerns.

"A theoretical calculation by Haug (1993) suggests that for particles larger than $1 \mathrm{~mm}$ in thickness, oxygen may not diffuse all the way into the center of the particle. Thus the interior regions of large particles are probably anaerobic, and decomposition rates in this region are correspondingly slow. However, anaerobic conditions are more of a problem with small particles, as the resulting narrow pores readily fill with water due to capillary action." Although it is apparent from the literature that reduced particle size increases the rate of solid waste degradation, there are limitations to its effectiveness. It may not be economical to achieve a uniform particle size using large scale grinding equipment and smaller particle sizes will increase pressure drop across the bed in a forced air system (this would increase the cost of supplying air to the reactors).

Table 5: Experimental Design to Test the Effect of Particle Size on the Rate of Solid Waste Degradation.

\begin{tabular}{|l|l|c|}
\hline & $\begin{array}{l}\text { Inoculum - (e.g., Sewage } \\
\text { Sludge...) }\end{array}$ & \\
\hline Particle Size Range & Feedstock 1 (Corn) & Feedstock 2 (Cabbage) \\
\hline$>2^{\prime \prime}$ & + & + \\
\hline $0.5^{\prime \prime}$ to 2" & + & + \\
\hline$<0.5^{\prime \prime}$ & + & + \\
\hline
\end{tabular}

\section{Moisture Content}

Adequate moisture is required for optimal microbial reproduction rates. Four or five different watering treatment regimes designed to maintain moisture content within specific ranges will be evaluated for their influence in biomass decomposition rates. The experimental design is shown in Table 6.

Table 6: Experimental Design to Test the Effect of Moisture Content on the Rate of Solid Waste Degradation.

\begin{tabular}{|l|c|c|}
\hline & Inoculum - (e.g., Sewage Sludge & \\
\hline Moisture Content & Feedstock 1 (Corn) & Feedstock 2 (Cabbage) \\
\hline $20-30 \%$ & + & + \\
\hline $40-50 \%$ & + & + \\
\hline $50-60 \%$ & + & + \\
\hline $60-70 \%$ & + & + \\
\hline
\end{tabular}




\section{Degradation Kinetics - Correlation with Microbiological Data}

The rate of solid waste degradation will depend on the microbiology of the process. The growth rate of the bacteria and fungi will be dependent not only on environmental parameters, but also on the interaction of microbial communities within the solid waste (of course environmental parameters can also affect the microbial community; e.g., composting at $60^{\circ} \mathrm{C}$ will select for thermophilic microorganism, but potentially reduce the microbial density and diversity). Consequently, the rate of solid waste degradation will depend on interactions within the community, as well as the initial types of microorganisms present (e.g., utilization of simple carbohydrates, such as glucose produced from cellulose breakdown by bacteria and yeast, will prevent feedback inhibition of cellulose and hemicellulose degradation by fungi and bacteria).

We will attempt to monitor both the total cell populations, as well as the types of microorganisms which develop during the composting process to obtain important process design information. These data will be correlated with the measured degradation rates to help standardize the process. The process must be standardized, since the proposed inoculums, although inexpensive, vary in microbial composition from batch to batch, and could lead to inconsistent performance. To determine the microorganisms in the inoculum responsible for the degradation process, it will be important to quantify the initial microbial composition of the inoculum and the change in the microbial community during the process. Although it is tempting to use specific strains of fungi (e.g., white rot fungi), research has shown that using a mixed microbial community promotes the degradation of structurally heterogeneous polymers such as lignocellulosics via synergistic effects; i.e., shorter lag times, higher rates and more complete degradation (Ljungdhal et al.,1977; Ejechi, 1994). In fact recent studies on the composting of bark and wheat straw, suggest that bacteria may play a major role in the degradation of lignocellulosics (Davis, 1993). Moreover, it would be prohibitively expensive to develop a large scale production facility for strain cultivation simply to produce a product of no value (solid waste which ultimately will be landfilled).

Both traditional and molecular methods will be used to monitor the microbial populations within the inoculum and during the composting process. In general, the analysis of microbial communities will be performed using a combination of methods. Conventional methods like direct counts, viable counts of total aerobic heterotrophic bacteria and fungi will be used to provide basic microbiological information. Direct counts will be performed using the acridine orange direct counts (AODC) method (Hobbie et al., 1977). Heterotrophic counts will be determined using selective media (e.g., nutrient agar for bacteria, Martin's rose bengal agar for fungi, or media with antibiotics to prevent bacterial growth, and starch-casein agar for actinomycetes). Activity probes, like cyanoditolyl tetrazolium chloride (CTC; to determine cytochrome activity) and diacetylfluorescein (DFA; to determine esterase activity) may be used to address issues 
concerning viability. Phylogenetic probes will be used to dissect microbial communities and to identify metabolically active populations. The compiled data will allow us to:

- Identify the required microorganisms in the inoculum and determine why one inoculum was better than another

- Provide a tool to measure the quality of the inoculum (i.e., will this particular batch of inoculum provide the same results as the last batch?)

- Provide information which can be used to develop better kinetics models to predict the rate of degradation and extent of solid waste conversion in the large scale process

The phylogenetic approach involves fluorescently labeled ribosomal probes of different levels of phylogenetic specificity used in a "nested" approach (Amann et al., 1995) to assess diversity, activity, and structure of microbial communities. Relevant to this study are probes that target: all organisms (Amann et al., 1990); eubacteria and archaea domains (Stahl and Amann, 1991); phylogenetically coherent groups such as alpha, beta, and gamma Proteobacteria (Manz et al., 1992), and high G+C Gram positive bacteria (Roller et al., 1994); specific aerobic bacteria like Pseudomonas spp. (Schleifer et al., 1992). Universal and eubacterial probes will be used to determine the number of detectable cells in the samples. Group and species specific probes will be used to study microbial composition and the effect of perturbations to microbial community structure.

\section{Micro-Composter Studies:}

The micro-composters will be small $(200-250 \mathrm{ml})$ bench scale reactors with periodic headspace sparging to maintain aerobic conditions (Fig. 5) Micro-composter experiments will be performed to determine the effectiveness of the inoculum, the effect of temperature, moisture content, and particle size on degradation rates. The effect of these parameters on the microbiology of the process will also be studied. The microcomposter units are standard components of a Micro-Oxymax (Columbus Instruments, Columbus $\mathrm{OH}$ ), a closed-circuit respirometer used to measure oxygen and carbon dioxide concentrations. The Micro-Oxymax has external $\mathrm{O}_{2}$ and $\mathrm{CO}_{2}$ sensors which measure the change in $\mathrm{O}_{2}$ and $\mathrm{CO}_{2}$ concentration with time in closed bioreactors. The objectives of these experiments will be to determine the best inoculum for lignocellulosic degradation and optimum conditions (e.g., temperature) for the composting process. These objectives will be accomplished by 1 ) measuring $\mathrm{O}_{2}$ and $\mathrm{CO}_{2}$ rates during degradation and 2) endpoint analysis of parameters such as dry weight and chemical composition of the composted plant material, and 3) quantifying change in the microbial populations (e.g., increase in cell densities and changes in the types of microorganism from time zero to the end-point). 
Since $\mathrm{O}_{2}$ is consumed and $\mathrm{CO}_{2}$ produced during lignocellulose degradation, the rate of $\mathrm{O}_{2}$ consumption and $\mathrm{CO}_{2}$ production is a measure of the rate and extent of biomass reduction. If the addition of microorganisms (inoculum), pretreatments, or changes in particle size for example, increase the rate of biodegradation, then the $\mathrm{O}_{2}$ consumption rate should be higher compared to a control. It should be noted that since $\mathrm{O}_{2}$ is consumed, consumption rates are reported as negative numbers. Based on this principle, the Micro-Oxymax has been used to measure the biodegradation rate of crude oil, diesel, and creosote contaminated soils (Berg et al. 1991, 1992).

Approximately 25-150 g of substrate (feedstock plus inoculum) will be added to the microcomposter units (Fig. 5). Each unit will be placed in a constant temperature bath and the inlet air stream to the reactor humidified to help maintain the moisture content of the feedstock. The Micro-Oxymax system will automatically pull headspace samples from the units and measure $\mathrm{O}_{2}, \mathrm{CO}_{2}$ and temperature. The headspace will be replaced with fresh air on a periodic basis. Both cumulative and instantaneous respiration rates will be acquired and stored on a IBM PC for later analysis. 

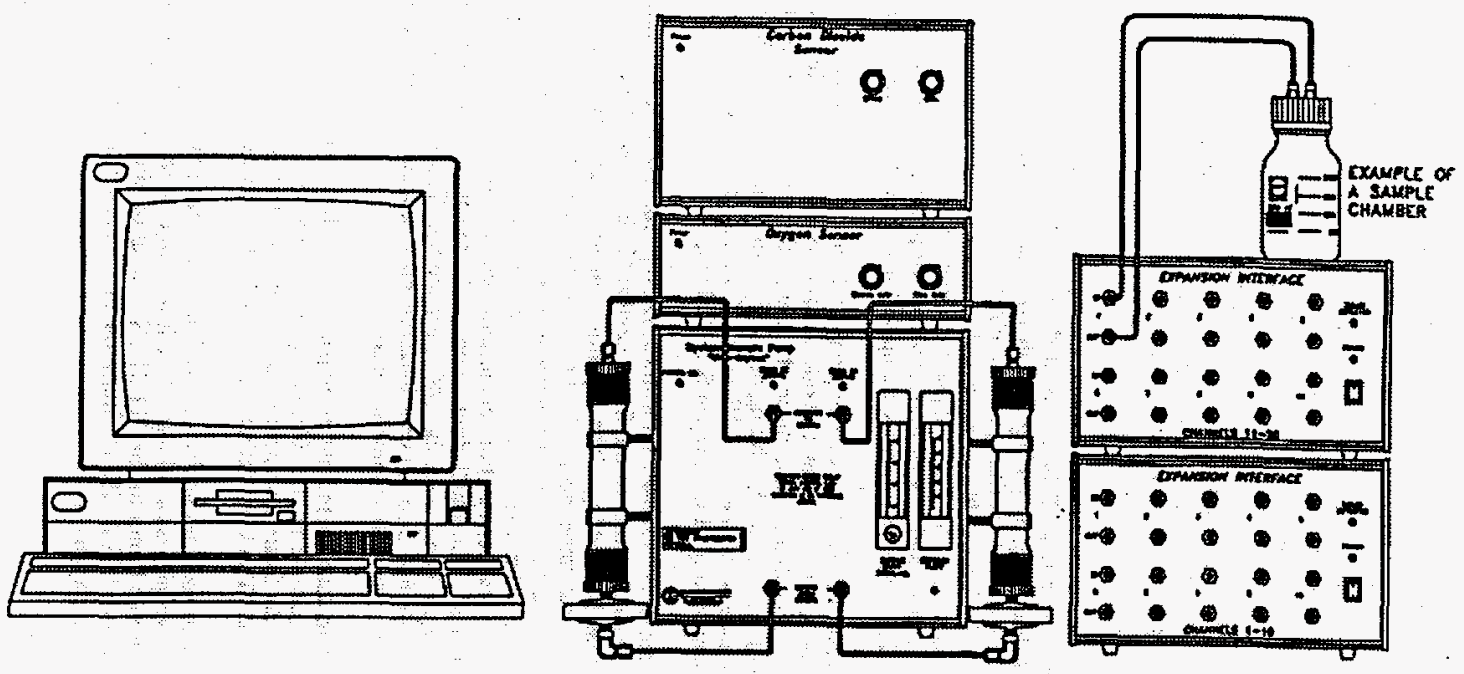

Figure 5: Micro-composter unit. A Bench Scale Reactor Used to Measure the Rate of Solid Waste Degradation by Periodic Headspace Sparging and by Automated Respiration Measurements.

\section{Mini-composter Studies}

The mini-composter units will be of a similar design as the reactors used in the microrespirometer (micro-composters), except that a false floor will be added to promote gas flow through the solid matrix and the units will be much larger $(500-1000 \mathrm{ml})$. The batch reactor will be similar to that reported in the literature (Magalhaes et al., 1993; Fig. 6). The reactors will be designed to promote air transport in a plug flow manner, with the air inlet located below a perforated false floor (to promote plug flow, the base of the reactors may contain gravel or large porous particles). Experiments using the minicomposters will utilize optimum conditions as determined by the small scale experiments (i.e., type of inoculum, initial moisture content, etc.) The objectives of these experiments will be to determine if the degradation rates measured at the small scale can be achieved when the reactor size is increased and to develop procedures to maintain optimum degradation rates within the reactor upon scale-up (i.e., control schemes for maintaining optimal moisture content and temperature). Three main parameters will be measured, temperature gradients; oxygen and carbon dioxide gradients, and moisture content. We will also take sub-samples from these reactors to measure the change in microbiology, as well as the composition of the solid waste. Because of the small reactor sizes in the micro-composter experiments representative samples will only be taken at time zero and the endpoint. The mini-composter experiments will allow us to obtain a time profile for 
the composition and microbiology, thus providing kinetic data which can be used to predict the behavior in the large scale reactors.

Threaded side ports or bulk head fittings will be installed for thermocouple installation to measure temperature gradients within the reactors. Additional ports will be installed along the length of the bed and/or at the top to measure $\mathrm{O}_{2}$ and $\mathrm{CO}_{2}$ profiles and to install moisture probes to monitor the water content of the biomass. Degradation rates will be estimated by measuring the rate of $\mathrm{O}_{2}$ consumption and $\mathrm{CO}_{2}$ production via the following methods: 1) a mass balance on the inlet and outlet streams (quasi steady state), 2) measuring the $\mathrm{O}_{2}$ and $\mathrm{CO}_{2}$ gradients along the length of the reactors (quasi steady state) and 3) a dynamic measure of $\mathrm{O}_{2}$ and $\mathrm{CO}_{2}$ after air flow termination (unsteady state), or obtaining sub-samples from the reactors and determining respiration rates in the MicroOxymax. Portable analytical devices capable of measuring $\mathrm{O}_{2}$ and $\mathrm{CO}_{2}$ will be used (Model 320P-4 $\mathrm{O}_{2}$ analyzer, Teledyne Analytical Instruments, City of Industry, CA and a GEM 500 LandTec, Commerce, CA; the GEM will also be used to measure static and differential pressure across the compost beds). The mini-composter units may have to be insulated to reduce heat loss and promote self-heating typical of large scale compost processes, (this will depend on the ultimate size and amount of biomass initially loaded into the reactors). 


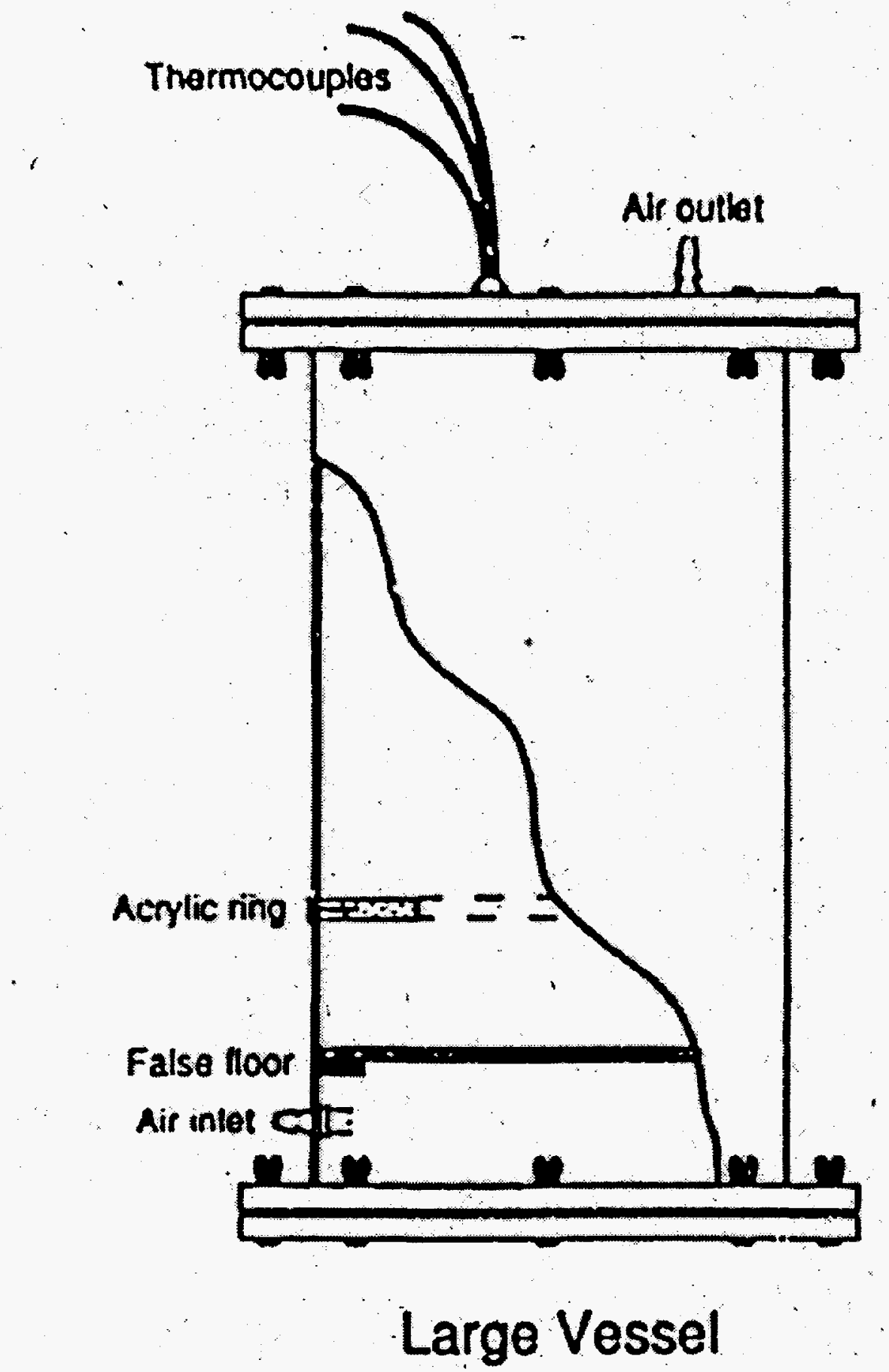

Figure 6: Mini Composter. A Batch Reactor Used to Compost Lignocellulosic Wastes (taken from Magalhaes et al., 1993) 


\section{Pilot-Scale Composters}

Larger (20-50 gallon, pilot scale) composting reactor vessels will be designed and constructed to further evaluate scale up and determine volume and weight reduction under optimal conditions as indicated by the micro- and mini- composter experiments. These large-scale reactors will be of the packed bed type and the surface to volume ratio will be increased to simulate a typical large scale composting reactor. It is suggested that one or more of the shipping containers be configured as a reactor. This would involve design of a false floor, installation of a temperature and moisture control system, installation of a manifold, and design of an easily accessible airtight lid (a HEPA filter system would also have to installed and tested). The pilot scale composting studies are presently scheduled to commence in FY 1998.

As described earlier, the bench scale experiments will be used to 1) determine the rate limiting steps and eliminate them (e.g., oxygen mass transfer), and 2) determine a rate law for the reaction (i.e., rate of oxygen consumption and solid waste consumption potentially coupled to the growth rate of the microorganisms). These data will then be used in the pilot scale experiments to set the initial conditions. The pilot scale reactors will, at a minimum, be an order of magnitude larger than the bench scale. The larger size will allow us to pinpoint scale-up problems such as channeling, increased pressure drop, and moisture control problems. Methods to control air humidity and the solid waste moisture content will be developed. The pilot-scale composters will be equipped with a humidification system and moisture probes will be installed in the reactors. The relative humidity of the inlet and outlet streams will also be monitored. Collection of these data will also help to develop moisture control strategies in the field scale demonstration. Overall, these large scale, fixed bed reactors will be used to determine the effect of scaleup on oxygen mass transfer rates, temperature profiles, pressure drops across the bed, moisture change, and the rate of biomass oxidation. Data from the pilot-scale reactors will be used to design and size larger reactors for field testing. 
Task/Milestone Summary:

FY $97 \quad$ FY 98

Task June July Aug Sept Oct Nov Dec Jan Feb March April May

1. Feedstock Preparation o-----o

2. Build Small Scale Reactors

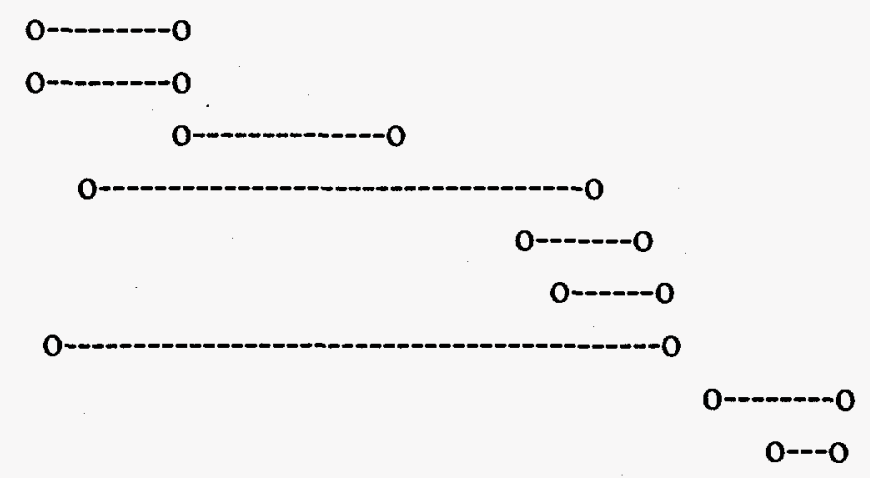

3. Inoculum Screening

4. Temperature Effects

5. Pretreatment Effects

6. Particle Size Effects

7. Moisture Content Effects

8. Measure Microbiology

9. Design Large Scale Reactor

10. Final Report 


\section{Safety}

All work will be done in accordance with general safety rules for the Savannah River Site, which are documented in the Savannah River Site (SRS) Safety Manual (8Q)and in compliance with DOE order 5483.1A. Savannah River Technology Center Safety Practices and Procedures Manual (8Q8) documents safety procedures for all activities of SRTC employees, SRTC visitors, and vendors/subcontractors.

\section{Quality Assurance}

All activities at SRS are governed by WSRC Quality Assurance Program as outlined in WSRC Management Policies, WSRC-1-01, MP 4.2. Specific quality assurance procedures are documented by organization as required. WSRC quality assurance is documented in WSRC Quality Assurance Manual (1Q).

\section{Security}

WSRC security requirements and procedures are documented in the WSRC Security Manual (7Q). These procedures are as required by federal laws and applicable DOE orders (e.g., DOE Order 5631.1A).

\section{Subcontracts}

A $\$ 20 \mathrm{~K}$ memorandum purchase order has been placed with the University of Georgia to allow their collaboration with SRTC on the project, primarily in providing chemical analyses using equipment not available at SRTC. 


\section{References}

Amann, R.I., W. Ludwig, and K.-H. Scheifer. 1995. Phylogenetic identification and in situ detection of individual microbial cells without cultivation. Microb. Rev. 59:143-169.

Amman, R. I., J. Stromley, R. Devereux, and D. A. Stahl. 1992. Molecular and microscopic identification of sulfate-reducing bacteria in multispecies biofilms. Appl. Environ. Microbiol. 58:614-623.

Amman, R. I., N. Springer, W. Ludwig, H. -D. Görtz, and K. -H. Scheleifer. 1991. Identification in situ and phylogeny of uncultured bacterial endosymbionts. Nature 351:161-164.

Amman, R. I., L. Krumholz, and D. A. Stahl. 1990. Fluorescent-oligonucleotide probing of whole cells for determinative, phylogenetic, and environmental studies in microbiology. J. Bacteriol. 172:762-770.

Berg et al., Treatment of Creosote-Contaminated Soil By Soil Washing and Slurry-Phase Bioreactors, 1992. Columbus Instruments, Micro-Oxymax Manual, Columbus $\mathrm{OH}$

Berg, Preliminary Testing of ECO/+ for Soil/Solids Bioremediation, 1991. Columbus Instruments, Micro-Oxymax Manual, Columbus $\mathrm{OH}$

Campbell, C. D., J. F. Darbyshire, and J. G. Anderson. 1990a. The composting of tree bark in small reactors - Adiabatic and fixed-temperature experiments. Biological Wastes. Vol. 31, pp. 175-185.

Campbell, C. D., J. F. Darbyshire, and J. G. Anderson. 1990b. The composting of tree bark in small reactors - Self-heating experiments. Biological Wastes. Vol. 31, pp. 145-161.

Davis, C.L., C.J. Donkin, S.A. Hinch, P. Germishuizen. 1993, Bioresource Technology (40) $195-204$.

Ejechi, B.O., C.O. Obuekwe. 1994, The Effect of Mixed Cultures of Some Microfungi and Basidomycetes on the Decay of Three Tropical Timbers, International Biodeterioation \& Biodegradation (33) 173-185.

Finstein, M.S., Hogan J.A., 1985. Integration of Composting Process Microbiology, Facility Structure and Decision-making, in Science\&Engineering of Composting: Design, Environmental, Microbiological and Utilization Aspects. (H.A.J. Hsitinh and H.M. Kneenor eds.) Renaissance Publications, Worthington, Ohio. pp. 1-23.

Gray, K.R., and K. Sherman. 1970. Public Cleansing 60(7):343-354.

Gray, K.R., K. Sherman, and A.J. Biddlestone. 1971. Process Biochemistry 6(10):22-28.

Gauthier J.J., J.A. Lushington, T.W. Federle, D.D. Jones, J.R. O' Brien, D.A. McMillon, Biochemical changes occurring during composting in a static pile and an in-vessel system., Annu. Madison Conf. Appl. Res. Pract. Munic. Ind. Waste (6th), Univ. Wis. -Ext., Dep. Eng. Appl. Sci., Madison, Wis. pp. 370-401.

Haug, R.T., 1993. Practical Handbook of Compost Eng'g. Lewis Publishers, Boca Ratan, FL. p.411. 
Hobbie, J. E., R. J. Daley, and S. Jasper. 1977. Use of Nuclepore Filters for Counting Bacteria by Fluorescence Microscopy. Appl. Environ. Microbiol. 33:1225-1228. Ljungdhal L.G., K-E Erikson, 1977, Ecology of Microbial Cellulose Degradation, Chapter 6, in Advances in Microbial Ecology, K.C. Marshall (ed.), Plenum Press, New York, p. 237-279.

Metcalf \& Eddy, (Tchobanoglous G., F.L. Burton., eds.) 1991. "Wastewater Engineering: Treatment, Disposal, and Reuse., Third Edition. pp. 842:850.

Magalhaes, et. al., 1993. Practical Simulation of Composting in the Laboratory, Waste Management \& Research (11) 143-154.

Manz, W., R. Amann, W. Ludwig, M. Wagner, and K.-H. Schleifer. 1992. Phylogenetic oligodeoxynucleotide probes for the major subcasses of proteobacteria: problems and solutions. Syst. Appl. Microbiol. 15:593-600.

Roller, C., M. Wagner, R. Amann, W. Ludwig, and K.-H. Schleifer. 1994. In situ probing of Gram-positive bacteria with high $\mathrm{G}+\mathrm{C}$ content using $23 \mathrm{~S}$ rRNAtargeted oligonucleotides. Microbiology 140:2849-2858.

Stahl, D. A., and R. Amann. 1991. Development and application of nucleic acid probes in bacterial systematics. In Nucleic acid techniques in bacterial systematics, E. Stackebrandt and M. Goodfellow (eds.). pp. 205-248. John Wiley and Sons Ltd., Chichester, England.

Tomati U., E. Galli, L. Pasetti, E. Volterra, 1995. Bioremediation of Olive-Mill Wastewaters by Composting, Waste Management \& Research (13) 509-518.

Viel. M., D. Sayag, A. Peyre, L. Andre, 1987. Optimization of In-Vessel Co-Composting Through Heat Recovery, Biological Wastes, 20: 167-185.

Webster T.S., J.S. Devinny, E.M. Torres, S.S. Basri, 1996. Microbial Ecosystems in Compost and Granular Activated Carbon Biofilters, Biotechnology and Bioengineering, 53(3): 296:303.

Wilde, E. W., C.E. Murphy, R. T. Lamar and M. J. Larsen. 1996. How to Deal with Radiologically Contaminated Vegetation. Westinghouse Savannah River Company, Savannah River Technology Center, Aiken, SC. (WSRC-TR-96-0125) 